\title{
ANALYSIS OF NEW EXPERIMENTAL BARLEY GENOTYPE PERFORMANCE FOR GRAIN YIELD USING AMMI BIPLOT
}

\author{
Milan Mirosavljević*, Novo Pržulj, Petar Čanak, ${ }^{1}$
}

\begin{abstract}
Resume
Presence of GE interaction reduces the correlation between genotypic and phenotypic parameters and complicates progress of selection. Among several methods proposed for evaluation of the GE interaction, the AMMI model is one of the most commonly used. The objective of this study was to estimate the GE interaction in new barley lines using the AMMI model, and to identify winter barley genotypes with stable and high yield. Multi-location trials with 25 winter barley advanced lines were conducted at four locations. The AMMI model was used to estimate GE interaction. The AMMI analysis of variance indicated that the genotype, environment and GE interaction had significant influence $(\mathrm{p}<0,01)$ on barley grain yield. Based on AMMI method, G8 and G18 could be recommended for further testing due their high and stable yields.
\end{abstract}

Key words: AMMI, genotype-by-environment interaction, grain yield, Hordeum vulgare L.

\section{Introduction}

Barley breeding and selection is a timeconsuming process that in many cases lasts over a decade. At the Institute of Field and Vegetable Crops, Novi Sad, plant breeders are constantly developing new barley cultivars, which have higher grain yield, quality and other desirable agronomical traits (Pržulj and Momčilović, 2010). One of the most important aims in barley breeding is the selection of superior genotypes from advanced generations.
In order to evaluate the performance of these genotypes, which could be potentially released as new cultivars, plant breeders conduct field trials at different locations. These tests enable collection of data about genotype stability and adaptability. Adaptability is the response of the genotypes to the differences between the locations (Lin and Binns, 1991), while stability represents the response of genotypes to variations between years (Lin and Binns, 1994). Multi-location trials usually consist of 20-30

Original scientific paper (Originalni naučni rad)

${ }^{1}$ Mirosavljević M, Pržulj N, Čanak P, Institut za ratarstvo i povrtarstvo, Maksima Gorkog 30, Novi Sad

"e-mail: milan.mirosavljevic@nsseme.com 
advanced genotypes and are conducted at locations that represent actual conditions in large scale productions.

Changes in cultivar performance across various environments are attributed to the effect of the genotype $\times$ environment (GE) interaction (Kang, 2004). Most important agronomical and economical traits such as grain yield, are quantitative in nature and routinely exhibit genotype $\mathrm{x}$ environment interaction (Dimitrijević and Petrović, 2000).Understanding of the GE interaction is important during the development of new adapted cultivars, since it reduces the correlation between genotypic and phenotypic parameters and interferes with the progress of selection (Comstock and Moll, 1963).

Among several methods proposed for evaluation of the GE interaction, the AMMI model is one of the most commonly used. It combines the analysis of variance (ANOVA) and the principal component analysis (PCA) in a single model (Gauch and Zobel, 1992). The AMMI biplot graphic display simultaneously both main and interaction effects for genotypes and environments, and enables a simple analysis of the GE interaction (Zobel et al., 1988). AMMI model has been used for understanding the GE interaction in various crops. Mitrović et al. (2012) tested this model for evaluation of 19 experimental maize hybrids across 12 environments. Also, Rodriguez et al. (2007) used the AMMI model to investigate GE interaction of different barley genotypes over Mediterranean environments. Marjanović-Jeromela et al. (2011) applied AMMI to evaluate rapeseeds genotype trials.

The objective of this study was to estimate the GE interaction using the AMMI model, and to identify winter barley genotypes with stable and high yield performance across different locations.

\section{Materials and methods}

Multi-location trials were conducted at four locations: Rimski Šančevi (RS), Sombor (SO), Pančevo (PA) and Sremska Mitrovica (SM) in season 2010/11, arranged in randomized complete block (RCB) design with three replications. The genetic material for this study were 25 winter barley genotypes (G1G25) developed at the Institute of Field and Vegetable crops, Novi Sad. The experimental plot size was $5 \mathrm{~m}^{2}$, with a plant density of 400 plants per $\mathrm{m}^{2}$. The planting and the harvest were performed by machine. Barley grain yield was adjusted to $14 \%$ moisture and expressed in $\mathrm{t} \mathrm{ha}^{-1}$. The application of mineral fertilizers was conducted based on agrochemical analysis.

The AMMI model was used to distinguish the genotype main effect, environment main effect and GE interaction, and it can be represented with the following formula (Zobel et al., 1988):

$$
Y_{g \theta r}=\mu+\alpha_{g}+\beta_{\theta}+\sum_{n=1}^{N} \lambda_{n} \gamma_{g n} \delta_{\theta n}+\rho_{g \theta}+\varepsilon_{g \theta r}
$$

where $Y_{g e r}$ is the yield for the genotype $g$ in the environment $e$ the replication $r, \mu$ is grand mean estimated with $\bar{Y}, \alpha_{g}$ is genotypic mean deviation from the total mean estimated from the difference $Y_{g}-\bar{Y}, \beta_{\theta}$ is the environmental mean deviation estimated from the difference $Y_{\theta}-\bar{Y}, \mathrm{~N}$ is the number of interaction principal component axis (IPCA), $\lambda_{n}$ is a singular value for $\mathrm{n}$ interaction principal component axis, $\gamma_{g n}$ is genotypic eigenvector 
for IPCA axis $n, \delta_{e n}$ is eigenvector of environment for IPCA axis $n, \rho_{g \theta}$ is a residue when not all PCA axis are included and $\varepsilon_{g e r}$ is an error.

Software STATISTICA 12 was used for two-way ANOVA, and the means were compared using LSD test. AMMI analyses were performed using Excel Biplot Macros (Lipkovich and Smith, 2002).

\section{Results and discussion}

The AMMI analysis of variance indicated that all three factors, the genotype, environment and GE interaction had significant influ- ence $(p<0,01)$ on barley grain yield (Table 1$)$. Based on Table 1, it is evident that environment had the highest effect on barley yield, and this factor explained $61,8 \%$ of treatment variation. GE interaction explained $25,7 \%$ of treatment interaction, while contribution of genotype in total treatment variation was $12,4 \%$. Yan and Rajcan (2002) similarly reported that environment had the highest effect on soybean yield. According to Stanisavljević et al. (2013), E explained $50-84 \%$ of treatment variation, $G$ accounted for 5,3-13,6\%, while GE explained $6,7-36,3 \%$ of treatment variation. Values of the first two IPCA axes were highly significant. IPCA 1 and IPCA2 accounted $71,4 \%$ and $20,5 \%$ of GE interaction, respectively. IPCA1 and IPCA2 accounted total $91,9 \%$ of GE in-

Table 1. The AMMI analysis of variance for barley grain yield

Tabela 1. AMMI analiza varijanse prinosa zrna ječma

\begin{tabular}{|c|c|c|c|c|c|c|c|}
\hline $\begin{array}{l}\text { Source of } \\
\text { variation/ }\end{array}$ & $\mathrm{df}$ & SS & MS & \multicolumn{2}{|c|}{ F-value } & $\begin{array}{c}\mathrm{G}+\mathrm{E}+\mathrm{GE} \\
\mathrm{SS}(\%)\end{array}$ & $\begin{array}{c}\text { GE SS } \\
(\%)\end{array}$ \\
\hline Total & 299 & 712,7 & 2,38 & & & & \\
\hline Treatments & 99 & 599,2 & 6,05 & 10,54 & $* *$ & & \\
\hline Genotypes & 24 & 74,6 & 3,11 & 5,41 & $* *$ & 12,4 & \\
\hline Environments & 3 & 370,6 & 123,53 & 302,32 & $* *$ & 61,8 & \\
\hline Interactions & 72 & 154,1 & 2,14 & 3,73 & $* *$ & 25,7 & \\
\hline IPCA1 & 26 & 110,0 & 4,23 & 7,37 & $* *$ & 18,4 & 71,4 \\
\hline IPCA2 & 24 & 31,6 & 1,32 & 2,30 & $* *$ & 5,3 & 20,5 \\
\hline IPCA3 & 22 & 12,5 & 0,57 & 0,99 & & 2,1 & 8,1 \\
\hline $\begin{array}{l}\text { Blocks within } \\
\text { Env. }\end{array}$ & 8 & 3,3 & 0,41 & 0,71 & & & \\
\hline Error & 192 & 110,2 & 0,57 & & & & \\
\hline
\end{tabular}

$d f$, degrees of freedom; SS, sum of squares; MS, mean square. **, $p<0.01$ 
teraction.

High percentage of treatment variation explained by environment indicated that agroecological conditions varied between tested environments. Average environment grain yield varied between 8,21 tha-1 in PA and 11,28 $\mathrm{t} \mathrm{ha}^{-1}$ in SM (Table 2). G8 was the highest yielding genotype with average grain yield of $11,17 \mathrm{t}$ ha $^{-1}$, followed with G5 which had average grain yield $10,85 \mathrm{tha}^{-1}$. The lowest yielding genotype was G10, and its average grain yield was 9,01 $\mathrm{t} \mathrm{ha} \mathrm{a}^{-1}$. Differences in genotype ranking i.e. differences in yield across various environments were also present. For example, in environment RS the most productive genotype was G5, while in environment SO G8 performed Table 2, Average grain yields ( $\left.t \mathrm{ha}^{-1}\right)$ of 25 barley genotypes across four environments Tabela 2, Prosečan prinos ( $\left.t \mathrm{ha}^{-1}\right) 25$ genotipova ječma u četiri sredine

\begin{tabular}{|c|c|c|c|c|c|}
\hline \multirow[t]{2}{*}{ Genotype (G) } & \multicolumn{5}{|c|}{$\begin{array}{l}\text { Environments }(\mathrm{E}) \\
\text { Grain yield }\left(\mathrm{t} \mathrm{ha}^{-1}\right)\end{array}$} \\
\hline & PA & RS & $\mathrm{SM}$ & $\mathrm{SO}$ & Average \\
\hline G1 & 7,57 & 8,73 & 10,77 & 9,22 & 9,07 \\
\hline G2 & 9,46 & 7,66 & 11,17 & 8,16 & 9,11 \\
\hline G3 & 9,83 & 9,37 & 10,40 & 8,08 & 9,42 \\
\hline G4 & 7,46 & 9,41 & 10,97 & 9,96 & 9,45 \\
\hline G5 & 10,85 & 10,89 & 12,36 & 9,28 & 10,85 \\
\hline G6 & 7,12 & 10,41 & 11,14 & 10,50 & 9,79 \\
\hline G7 & 9,54 & 9,09 & 11,65 & 9,91 & 10,05 \\
\hline G8 & 10,15 & 10,33 & 12,12 & 12,08 & 11,17 \\
\hline G9 & 9,45 & 8,86 & 12,06 & 9,63 & 10,00 \\
\hline G10 & 7,86 & 8,65 & 10,65 & 8,87 & 9,01 \\
\hline G11 & 8,28 & 9,26 & 10,46 & 9,24 & 9,31 \\
\hline G12 & 9,03 & 8,93 & 11,33 & 10,30 & 9,90 \\
\hline G13 & 8,17 & 10,03 & 11,41 & 9,48 & 9,77 \\
\hline G14 & 7,66 & 9,91 & 10,82 & 10,46 & 9,71 \\
\hline G15 & 7,60 & 9,16 & 11,64 & 10,72 & 9,78 \\
\hline G16 & 8,04 & 8,82 & 11,66 & 10,52 & 9,76 \\
\hline G17 & 7,55 & 10,47 & 10,58 & 10,76 & 9,84 \\
\hline G18 & 8,63 & 9,40 & 11,96 & 11,05 & 10,26 \\
\hline G19 & 7,78 & 10,01 & 10,92 & 10,85 & 9,89 \\
\hline G20 & 6,63 & 10,04 & 10,41 & 10,44 & 9,38 \\
\hline G21 & 7,25 & 10,35 & 11,20 & 10,87 & 9,92 \\
\hline G22 & 7,18 & 10,31 & 12,12 & 11,05 & 10,17 \\
\hline G23 & 7,39 & 9,45 & 11,83 & 10,64 & 9,83 \\
\hline G24 & 8,04 & 7,63 & 10,82 & 10,34 & 9,21 \\
\hline G25 & 6,67 & 9,31 & 11,63 & 10,23 & 9,46 \\
\hline Average & 8,21 & 9,46 & 11,28 & 10,11 & - \\
\hline LSD & G & & $\mathrm{E}$ & & \\
\hline 0,05 & 0,61 & & 0,24 & & \\
\hline 0,01 & 0,80 & & 0,32 & & \\
\hline
\end{tabular}


better than other genotypes.

According to Zobel et al. (1988), traditional statistical methods (ANOVA, PCA and linear regression) are often not effective for understanding and evaluating complex data from multi-environments yield trials. In contrast to the standard statistical analyses, AMMI incorporates ANOVA and PCA into a single model and enables simple visual interpretation of the GE interaction. AMMI model is usually constructed from the first two IPCA axes, although some researchers use model with first three or four IPCA axes (Sivapalan et al., 2000). Most of the noise appears in the interaction effect, since the interaction effect has more degrees of freedom than genotype and environmental main effects. IPCA1 axis captured the highest percentage of the interaction effect that is closest to linearity. Each of the following axes is perpendicular to the previous, capturing less of the explained variation and involving more noise due to the increased number of the degrees of freedom (Babić et al, 2011). The models AMMI1 and AMMI2 are the most frequently used, because the higher-order IPCA axes are more burdened by the noise. According to Kaya et al. (2002) the most accurate model for AMMI can be predicted by using the first two
IPCAs. Further, Gauch and Zobel (1996) stated that third and higher IPCA have no predictive value and no biological interpretability, since they are dominated by noise.

In the AMMI1 biplot, $\mathrm{x}$ axis represents the genotypes and environment main effect and $y$ axis represents the effects of interaction (Figure 1). Therefore genotypes that have small IPCA1 values are more stable. The majority of genotypes had grain yield close to average yield, but they had different IPCA1 values. Genotypes G18, G13, G16, G1, G24 and G8 could be separated as the most stable genotypes. Among them, grain yield of G1 and G24 was among the lowest and therefore these two genotypes should not be used for further testing. On the other hand, genotypes G2 and G3 were the most unstable genotypes with low average yield. According to this traits, G2 and G3 should not be recommended for further breeding program. Genotypes G13, G16 and G18 were among the most stable genotypes with grain yield close to overall average. Genotypes G8, G5, G18 and G22 could be highlighted as most productive genotypes. Although these genotypes had high yield, G8 and G18 had better stability and represents a desirable genotype in further barley breeding process. 


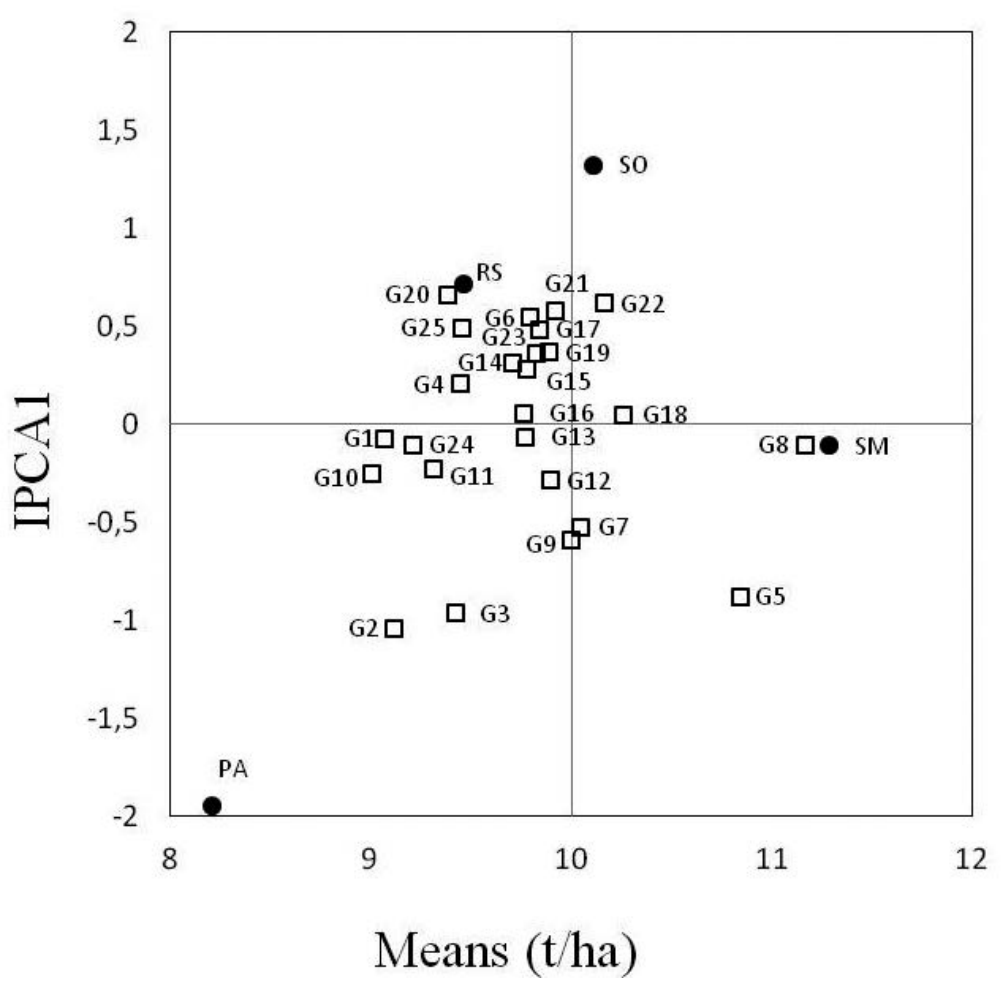

Figure 1. AMMI1 biplot of 25 barley genotypes across four environments Slika 1. AMMI1 biplot 25 genotipa ječam u četiri sredine

Location SM stood out as environment with small contribution to GE interaction and high average yield. The main reason for high average yield in this environment are the optimal climate conditions that occurred during the crop cycle and relatively higher natural fertility of soils compared with the other environments such as PA. RS was intermediate contributor to the interaction. On the other hand, environ- ments PA and SO had the highest IPCA1 value, which indicates that these environments contributed most to the GE interaction. For example G3 was the lowest yielding genotype in SO, while in PA was third highest yielding genotype (Table 2). 


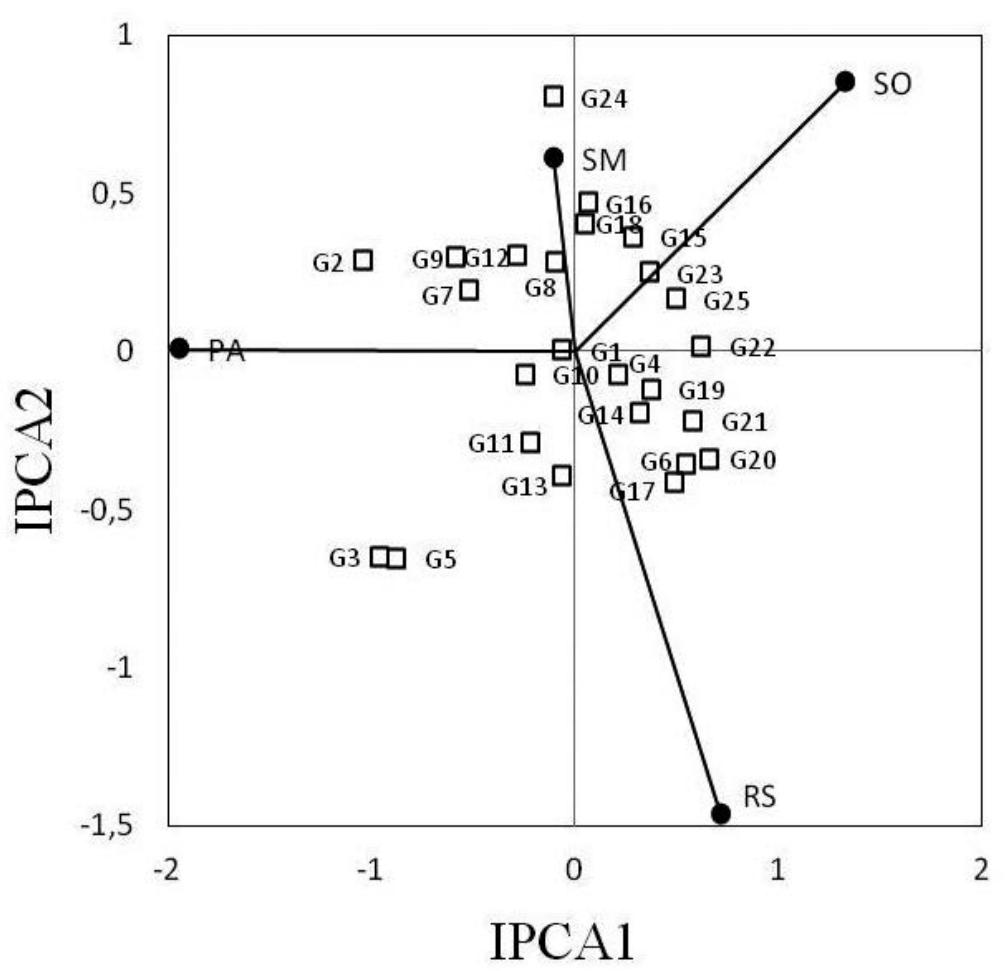

Figure 2. AMMI2 biplot of 25 barley genotypes across four environments Slika 2. AMMI2 biplot 25 genotipa ječam u četiri sredine

AMMI2 biplot was constructed using genotypic and enivronmental scores of the first two IPCA axes (Figure 2). Genotypes positioned close to the biplot origin are more stable compared to the genotypes positioned further away. Among tested cultivars, G1, G10 and G4 could be separated as the most stable genotypes. On the other hand, G24, G2, G3 and G5 were placed further from the biplot origin, which indicates that these genotypes have specific adaptation. Genotypes that were positioned close together have positive association. For example, G3 and G5, and G16 and G18 were highly associated. Association between these genotypes was expected since they originated from similar genetic pool. Additionally, in the AMMI2 biplot, genotypes and environments that are placed close to each other have positive association, which enables creation of specific agronomic zones. For instance, G16, G18 and G24 were positioned near the environment $\mathrm{SM}$, whereas $\mathrm{G} 2$ was adapted to PA.

\section{Conclusion}

Based on this study, it could be concluded that AMMI1 and AMMI2 are very applicable for analysis of barley multi-location 
trials. The results enabled better understanding of barley genotypes performance over several environments, and selection of stable and high yielding genotypes. Among tested genotypes, G2 and G3 were the most unstable genotypes, with average grain yield among lowest and therefore, these genotypes should be excluded from further breeding program. On the other hand, G8, G5, G18 and G22 could be separated as highest yielding genotypes. Furthermore, due its better stability G8 and G18 could be recommended for further testing. These results could be considered as preliminary, and for further selection of desirable genotypes it would be necessary to conduct trials on an increased number of locations over several years. Besides G8 and G18, genotypes with lower stability and high average yield should be included in these trials.

\section{Acknowledgements}

This paper presents results of the project TR-31066, supported by Ministry of Education, Science and Technological Development of Republic Serbia.

\section{Reference}

Babić M, Babić V, Delić N, Prodanović S, Anđelković V (2011): The comparison of stability parameters according to the Finlay-Wilkinson, Eberhart-Russell and AMMI model. Selekcija i semenarstvo, 17 (2): 35-40.

Comstock RE, Moll RH (1963): Genotypeenvironment interaction. In: WD Hansen and HF Robinson (ed) Statistical genetics and plant breeding. NASNRC, Publication: 982, Washington D. C., 164-196.

Dimitrijević M, Petrović S (2000): Adaptability and stability of genotypes. Selekcija i semenarstvo, 7 (1-2): 21-28.

Gauch HG (1992): Statistical analysis of regional yield trials: AMMI analysis of factorial designs. Elsevier, Amsterdam, Netherlands.

Gauch GH, Zobel RW (1996): AMMI analysis of yield trials. In: MS Kang and HG Gauch (ed) Genotype by environment interaction. CRC Press, Boca Raton, FL, 85-122.

Kang MS (2004): Breeding: Genotype-byenvironment interaction. In: RM Goodman (ed) Encyclopaedia of Plant and Crop Science. Marcel-Dekker, New York, 218-221.

Kaya Y, Palta C, Taner S (2002) Additive main effects and multiplicative interactions analysis of yield performances in bread wheat genotypes across environments. Turk. J. Agric. For. 26: 275-279.

Lin CS, Binns MR (1991): Assessment of a method for cultivar selection based on regional trial data. Theor. Appl. Genet. 82: 505-509.

Lin CS, Binns MR (1994): Concepts and methods of analyzing regional trial data for cultivar and location selection. Plant Breeding Reviews, 12: 271297.

Lipkovich I, Smith EP (2002): Biplot and singular value decomposition macros for Excel. J. Stat. Softw. 7 (5):1-15.

Marjanović-Jeromela A, Nagl N, GvozdanovićVarga J, Hristov N, Kondić-Šspika A, Vasić M, Marinković R (2011): Genotype by environment interaction for seed yield per plant in rapeseed using AMMI model. Pesqu. Agropecu. Bras. 46: 174-181.

Mitrović B, Stanisavljević D, Treskić S, Stojaković M, Ivanović M, Bekavac G, Rajković M (2012): Evaluation of 
experimental maize hybrids tested in multi-location trials using AMMI and GGE biplot analyses, Turk. J. Field Crops, 17 (1): 35-40.

Pržulj N, Momčilović V, Nožinić M, Jestrović Z, Pavlović M, Orbović B (2010): Importance and breeding of barley and oats. Ratar. Povrt. 47 (1): 33-42.

Rodriguez M, Rau D, Papa R, Attene G (2007): Genotype by environment interactions in barley (Hordeum vulgare L.): different responses of landraces, recombinant inbred lines and varieties to Mediterranean environment. Euphytica, 163: 231-247.

Sivapalan S, Brien LO, Ferrara GO, Hollamby GL, Barclay I, Martin PJ (2000): An adaptation analysis of Australian and CIMMYT/ICARDA wheat germplasm in Australian production environments. Aust. J. Agric. Res. 51: 903-915.

Stanisavljević D, Mitrović B, Mirosavljević M, Ćirić M, Čanak P, Stojaković M, Ivanović M (2013): Identification of the most desirable maize testing environments in northern Serbia. Ratar. Povrt., 50(2): 28-35.

Yan W, Rajcan I (2002): Biplot analysis of test sites and trait relations of soybean in Ontario. Crop Sci. 42: 11-20.

Zobel R, Wright MJ, Gauch HG (1988): Statistical analysis of yield trial. Agron. J, 80: 388-393. 


\title{
ANALIZA PERFORMANSI NOVIH EKSPERIMENTALNIH GENOTIPOVA JEČMA ZA PRINOS ZRNA POMOĆU AMMI BIPLOTA
}

\author{
Milan Mirosavljević, Novo Pržulj, Petar Čanak,
}

\section{Izvod}

Interakcija GxE je izvor varijacije koji uključije uticaj genotipa i faktora spoljašnje sredine, koji otežava izbor superiornih genotipova u procesu selekcije. AMMI analiza predstavalja metod koji se često koristi za ocenu interakcije genotip/sredina. Cilj ovog rada je ocena interakcije genotip/sredina pomoću AMMI modela, i identifikacija genotipova ozimog ječma sa visokim i stabilnim prinosom. Multilokacijski ogledi sa 25 superiornih linija ječma su posejani na četiri lokaliteta. AMMI analizom varijanse je utvrđeno da su genotip, sredina i interakcija genotip/ sredina imali signifikantan uticaj $(\mathrm{p}<0,01)$ na prinos ječma. Na osnovu AMMI analize, genotipovi G8 i G18 se mogu preporučiti za dalje testiranje usled njihovog visokog i stabilnog prinosa.

Ključne reči: AMMI, Hordeum vulgare L., interakcija genotip/sredina, prinos zrna,

Primljeno: 13. 04. 2014.

Prihvaćeno: 30. 05. 2014. 